\title{
Elasticity of the Settlement Structure and Expansion of Settlements into the Landscape: The Shares of the Built Area and the Plots for Building Development
}

\author{
Elasticita sídelní struktury a rozvoj sídel do krajiny: \\ podíl zastavěného území a zastavitelných ploch \\ v krajině
}

Barbora Jenčková

Ústav prostorové tvorby, Fakulta architektury, Vysoké učení technické v Brně školitel: doc. Ing. arch. Jiří Palacký, Ph.D.

\begin{abstract}
The settlement structure undergoes a permanent change. Urbanization has been accompanied by gradual expansion of settlements into the landscape. In metropolitan areas, an increased demand for development areas creates pressure for identifying further plots to build at the expense of undeveloped landscape. The extent of existing urbanization around a metropolis is often not directly dependent on the natural conditions and morphology of the area, the distance and the relation to the metropolitan center being decisive. Settlements are forced to cope with change. An essential property of settlement structures is therefore adaptability. The elasticity of the settlement structure is therefore presented as a value that allows responding to changes. On the basis of theoretical conclusions, verified through case studies, the properties and characteristics of elastic settlement structures will be determined.
\end{abstract}

KEYWORDS: structure elasticity; settlement structure; area adaptability; urban development; settlement; urban sprawl; lifestyle; cultural landscape

ABSTRAKT: Sídelní struktura prochází permanentní proměnou. Dosavadní urbanizaci provází postupné rozpínání sídel do krajiny. V metropolitních oblastech se zvýšená poptávka po rozvojových plochách projevuje tlakem na vymezování dalších zastavitelných ploch na úkor volné krajiny. Míra stávající urbanizace v okolí metropole není často př́mo závislá na přírodních podmínkách a morfologii území, rozhodující je spíše vzdálenost a vztah k metropolitnímu centru. Sídla jsou nucena se s proměnami vyrovnávat. Podstatnou vlastností sídelních struktur je proto adaptabilita. Elasti- 
cita sídelní struktury je proto představována jako hodnota, která umožňuje reagovat na změny. Na základě teoretických závěrů, ověřených na případových studiích, budou stanoveny vlastnosti a charakteristiky elastických sídelních struktur.

KLÎ́ČOVÁ SLOVA: elasticita struktury; sídelní struktura; adaptabilita území; územní rozvoj; osídlení; sídelní kaše; životní styl; kulturní krajina

\section{Úvod}

Příspěvek se zabývá sídelní strukturou a její adaptabilitou v souvislosti s proměnou sídel, zejména jejich plošným rozvojem do volné krajiny. Na adaptabilitu sídelních struktur je pohlíženo z hlediska dopadů na tvorbu územněplánovacích dokumentací jakožto legislativních prostředků ovlivňujících zásadním způsobem vývoj území.

Sídelní struktura se permanentně proměňuje v čase. Sídla se stále přetvářejí tak, aby uspokojila měnící se potřeby svých uživatelů, aby reagovala na vnější vlivy a podněty. Působí na ně enormní množství faktorů. Docilují proměny jednak vnitřní restrukturalizací, jednak plošnou expanzí do okolního prostoru volné krajiny (suburbanizací).

\section{Rozšiřování sídel do krajiny}

Rozšiřování sídel do krajiny je stále zdánlivě nejsnazším způsobem rozvoje sídel. Nejvýraznější je v současnosti v perimetru velkých měst, kde se výrazná suburbanizace projevuje proměnou původně svébytných sídel v obce závislé na centrální metropoli. Vysoká poptávka po nové výstavbě směřuje především do nejbližšího venkovského okolí města. Týká se nejen zájmu o kapacity bydlení (i když tento je velmi výrazný), ale také výrobních a logistických objektů, které jsou z pohledu zásahu do původních struktur osídlení a do krajinného zázemí ještě problematičtější.

Město (metropole) je v kontextu této práce sídlo disponující komplexní nabídkou funkcí, které vyvolává při uspokojování poptávky po volných stavebních pozemcích suburbanizaci širšího okolí v navazujícím - venkovském prostředí. Nadměrná urbanizace příměstských obcí snadno poruší rovnováhu funkčních vazeb takových sídel. Venkovská sídla nedisponují komplexní nabídkou funkcí a jsou na metropoli při postupující urbanizaci stále závislejší.

Jedním z východisek výzkumu je proto míra plošného rozrůstání sídel. Výzkum srovnává poměr mezi zastavěným územím (zastavěné území ve smyslu $₫ 58$ zákona 183/2006 Sb.) a volnou krajinou - nezastavěným územím. 
Dále se zabývá mírou navrženého plošného rozvoje v platných územněplánovacích dokumentacích, protože postupné naplňování těchto vizí se v sídelní struktuře projevuje se zpožděním, vzájemný synergický efekt některých zásahů má pak citelný dopad na sídelní strukturu.

Sídelní struktura je nucena se $s$ neustále přicházejícími změnami vypořádávat. Schopnost vyrovnat se s podněty je nazývána adaptabilitou. Struktura, která dokáže vstřebávat podněty a reagovat na ně úpravou své vlastní organizace, je elastická. Chová se tedy obdobně jako živý organismus. Sídelní struktura může mít obdobné vlastnosti jako př́rodní struktury.

\section{Elasticita jako hodnota sídla}

Elasticita je zde definována jako schopnost sídelní struktury proměňovat se dle stále se měnících požadavků na funkční využití a prostorové i jiné parametry a reagovat na nejrůznější podněty, které vývoj přináší.

Elasticita je tedy hodnota, je základním předpokladem trvání a přežití sídla.

Urbánní struktura je nejpodstatnější materií prostoru sídla, vkladem člověka jako tvůrce organizace území. Její budování bylo vždy náročné a ovlivněné velkým množstvím faktorů. Měla by tedy být schopna takového vývoje, který prokáže její životaschopnost i při změně vnějších či vnitřních podmínek. Nepřizpůsobivost struktur, jejich neschopnost reagovat na změny, se projevuje jejich zánikem, likvidací, nahrazováním strukturami novými. Likvidace původní struktury vždy znamená náročný zásah do organismu sídla - „operaci“, která může mít za následek jak ozdravný efekt, tak negativní účinky, jejichž dosah není odhadnutelný.

Ideální urbanistickou strukturou je tedy takové uspořádání prvků, prostorů a vazeb, které dokáže pružně reagovat na proměnu podmínek.

Další výzkum je proto věnován zkoumání vlastností, které vedou k vývoji elastických struktur. K tomu je využíán jednak teoretický základ prostudované literatury, jednak praktický výzkum - prŕípadové studie.

\section{Teoretická východiska}

\section{Vznik a vývoj struktur sídel}

Urbánní rozvoj se stále zrychluje. Růst sídel tvoří spojitou nádobu s růstem a dynamikou ekonomiky. 20. století přineslo prudký ekonomický růst a 21. století je prová- 
zeno neustálým zrychlováním ekonomického vývoje. Přímý vztah mezi ekonomikou a urbanizací byl řešen $v$ různých empirických studiích a bylo konstatováno, že globální struktura růstu měst v kontextu ekonomiky je velmi podobná bez ohledu na kulturní rozdíly a bez ohledu na rozdíly v morfologické struktuře jednotlivých měst. (Bettencourt, 2007)

\section{Paralely}

Teoretickým východiskem výzkumu elasticity sídelních struktur jako paralely sídelní struktury s př́rodními strukturami je práce N. Salingarose a M. W. Mehaffyho, která hovoří o tom, že přírodní struktury užívají k vytváření nových celků transformaci, u níž je klíčová genetická informace, určující, jak systémy rostou, jak jsou udržovány.

Informace jsou důležitým vodítkem pro tvorbu návrhů. Nejedná se o předurčenost - řešení mohou mít více variant, ale přitom dodržují základní jednotu - celistvost a řád. Transformace je základním prostředkem generačního vývoje, který vychází z několika př̀edků a dosahuje postupně komplexity. Mezi vlastnosti živých struktur patří sítová propojenost, různorodost funkcí a redundance, široká distribuce struktur např́č úrovněmi, schopnost sebeorganizace. (Mehaffy, 2015) Obdobným způsobem se chovají sídelní struktury.

Člověk vytváří struktury, které jsou součástí jednoho a téhož světa podobně jako struktury přírodní, člověk je součástí prrírody, je proto zřejmé, že fungující systémy mají shodné požadavky a pravidla uspořádání: vzájemnou propojenost, vztahy, potřebu vytvářet různorodost až nadbytek aktivit, typů, objektů.

\section{Multimodalita, mnohočetnost vazeb}

Struktury sídel je třeba utvářet jako dostatečně přizpůsobivé, abychom se dokázali vypořádat s nepředvídatelnými událostmi. Mnohé realizované př́klady však poukazují na opak (nevhodnost koncentrace vybavení a infrastruktury způsobující snadnou zranitelnost $\mathrm{v}$ př́ípadě nenadálé události). Požadavek adaptability směřuje $\mathrm{k} v \mathrm{v}$ tváření multimodálních systémů, které jsou podstatně odolnější, protože podstatné je rozloženo do mnoha bodů a ztráta jednoho z nich proto neznamená nefunkčnost systému.

Podstatná pro organizaci struktury je její hierarchie. Lidmi vytvořené struktury by měly být hierarchicky strukturovány, protože hierarchizace zajistí snadnější úpravy nefunkčních částí. Zdravý organismus reaguje na změnu adaptací struktur, reaguje na výkyvy sám úpravou své organizace. 


\section{Sebeorganizace}

Schopnost vlastní organizace živé struktury se promítá i do úvah o způsobu utváření struktur a dále do možností prostorového plánování (územního plánování). Co se týče organizace sídel, postmoderní teze uvádí, že věda není schopna ovládat společnost a prostor a neměla by se o to snažit. (Alfasi, 2004) Teze je prrímým protikladem myšlenky, že město funguje jako stroj, která byla základem systému plánování shora nazývaného také taylorismus (podle Taylorova vědeckého řízení 1911-1947) a fordismus (podle mechanizovaných hromadných výrobních metod propagovaných Henrym Fordem (1863-1947)) a je reprezentována plánováním typu „just in case“ (Alfasi, 2004), které je základem většiny modelů územního plánování, jež jsou strukturovány od územního plánování celku k podrobnějším stupňům plánovací dokumentace.

Př́stup založený na „sebeorganizaci“ je tedy jiný, odkazuje se na systémy, které jsou komplexní a otevřené v tom smyslu, že jejich hranice umožňují tok materiálu a informací a je těžké předvídat a řídit další vývoj (například město). Řád a stabilita se procesem „sebeorganizace“ spontánně objevují zevnitř systému.

Sídlo v sobě přirozeně obsahuje mnoho plánovacích procesů - plánování obcí, firem všech velikostí, projektů různého druhu. Obrovský je počet aktérů plánování, mezi něž patří i jednotlivci, rodiny, projekty nejrůznějších druhů staveb: obytných i polyfunkčních budov, kanceláří a průmyslových struktur, nákupních center, čtvrtí, parků, komunikací. Prostorové uspořádání je sídlu zdánlivě vrozené v důsledku existujících vzájemných vztahů mezi různými plány a jako následek budování prostředí. Cíl územního plánování regulovat to, co se ve městě děje, nebo určovat pořadí těchto (např.) akcí, je odsouzen k neúspěchu. (Portugali, 2000)

\section{Trvanlivost struktur}

Sídelní struktury jsou formovány systémy vazeb - dopravních a energetických toků, - a jejich vznik je podmíněn přírodními podmínkami a morfologií území, krajinným rázem (Löw, 2003). Míra ovlivnění přírodou je odlišná zejména s ohledem na historický vývoj urbánní struktury v době př́mé vazby sídel na potravní základnu, což je dobře rozlišitelné při srovnání osídlení jihomoravského a slovinského venkova. Typologie a morfologie sídel utvořené před mnoha staletími jsou stále základem sídelní struktury, která se kontinuálně adaptuje na nové podmínky.

Výzkum pracuje s hypotézou, že kvalita prostředí a funkčnost sídel jsou úměrné víceúčelovosti a pestrosti vazeb v území, tedy adaptabilitě - schopnosti transformace stávajících struktur dle změny podmínek $\mathrm{v}$ čase. 
Postupně utvářená struktura osídlení podle předpokladu disponuje takovou strukturou vazeb, která poskytuje dostatečnou elasticitu vzhledem ke změnám podmínek. Schopnost transformace má zásadní vliv na další rozvoj sídel, je úzce propojena s udržitelným rozvojem území.

\section{Metody výzkumu}

Míra plošného rozrůstání sídel je zkoumána pro na základě dostupných dat o území $\mathrm{v}$ rámci Jihomoravského kraje.

O vzájemném poměru zastavěných ploch a volné krajiny u nás dává představu srovnání současného stavu zastavění na Židlochovicku a Blanensku.

Stávající stav území - vztah mezi zastavěnými územími a volnou krajinou - je vyhodnocen pomocí map LANDUSE 2017 pro správní území dvou obcí s rozšířenou působností (ORP). Mapa LANDUSE 2017 dává v širším měřítku rámcový přehled o plošném rozložení funkcí v území. Mapové výstupy i grafy dokumentují odlišnost krajiny v obou sledovaných oblastech. Polní krajina Židlochovicka je zcela odlišná od lesnatého Blanenska. Míra zastavěnosti v rámci ORP je však velmi podobná, patrně je mnohem silněji ovlivněna přibližně stejnou vzdáleností od metropole - Brna, obdobnou dostupností metropole a společenskými vlivy.

Na základě vymezení zastavitelných ploch v platných územních plánech je plánován plošný rozvoj zástavby do krajiny - opět jsou srovnávány oblasti Židlochovicka a Blanenska. (Srovnání vychází z územněanalytických podkladů ORP 2016 - 4. úplná aktualizace - jevy zastavěné území a zastavitelné plochy.)

Srovnání poskytuje představu o současném a navrhovaném zastavění krajiny. Jevy zastavěné území i zastavitelné plochy jsou převzaty z jednotlivých územních plánů obcí a měst platných $\mathrm{k}$ datu vyhotovení ÚAP ORP. Rozvojové plochy v prezentovaném rozsahu jsou tedy závazně vymezeny obecními vyhláškami nebo opatřeními obecné povahy s platností k 12/2016. Plošná velikost vymezených zastavitelných ploch se přehledně srovnává s plochami zastavěných území a hodnoty jsou pro obě tyto př́městské oblasti obdobné.

Očekávaný rozvoj, často vymezený starší územněplánovací dokumentací, se v mnoha př́padech nenaplnil, naopak sídla exponovaná v uzlových bodech sídelní struktury možnosti rozvoje již vyčerpala.

Lze hodnotit poměr zastavitelných ploch, zastavěných ploch a volné krajiny a zabývat se dále úměrou zastavitelných ploch vzhledem k současnému rozsahu zastavitelných 
území a pozici obce ve struktuře osídlení.

Otázkou pro další výzkum zůstává, zda vzájemný poměr zastavěných území a zastavitelných ploch je adekvátní očekávanému demografickému vývoji a poloze sídel v sídelní struktuře. Podstatné je, jak jsou sídla schopna absorbovat takovýto objemový nárůst a adaptovat se na nové podmínky.

Rozpínání ovlivňuje jak sídla a jejich strukturu, tak volnou krajinu, která se stává stále cennější.

Teoretická východiska jmenují vlastnosti, kterými disponují elastické struktury.

Tyto vlastnosti jsou proto prověřovány v prrípadových studiích.

Jsou sledována sídla v oblasti Blanenska a Židlochovicka. V obou př́ípadech se jedná o území v metropolitní oblasti Brna, kde dochází k dynamickým proměnám, které vyvíjejí tlak na adaptabilitu sídelních struktur.

Obrazová příloha dokumentuje na schematické mapě rozsah zastavěného území a zastavitelných ploch v rámci oblasti Židlochovicka, obdobně jsou zpracovávány další oblasti v rámci Jihomoravského kraje.

Jak dokládá rozsah ploch pro plošný rozvoj, jedná se v mnoha případech o podstatný zásah do struktury sídel, která jsou nucena se s novou situací vyrovnat.

Pro další srovnání je využit příklad obce Mengeš (POTOČNIK, 2013) a oblasti stř̌edního Slovinska. Srovnání je použito, protože vývoj př́městských oblastí ve sledovaných územích obou zemí má poměrně obdobnou historii. Původní svébytná sídla $\mathrm{v}$ okolí měst jsou postupně pohlcována dostředivou silou metropole a ztrácejí svou funkční samostatnost. Významnější uzly byly zasaženy již dříve socialistickou hromadnou bytovou výstavbou (Židlochovice, Blansko i slovinské Domžale), v menších sídlech se o to výrazněji propisují zásahy z devadesátých let 20. stol. a novější. Tehdy vznikaly kobercové zástavby rodinných domů (Holasice $15 \mathrm{~km}$ od Brna na Židlochovicku, Mengeš cca $17 \mathrm{~km}$ od Lublaně). Nové lokality zpětně působí na stávající struktury obcí, zejména co se týká adaptability jejich infrastruktury.

\section{Výsledky výzkumu}

Výsledky výzkumu budou použity v disertační práci. Na základě dosavadních zjištění lze konstatovat, že je pravděpodobné, že růst sídel v kontextu ekonomiky je velmi podobný bez ohledu na rozdíly v morfologické struktuře. (Bettencourt, 2007) 
Je prováděn průzkum vlastností adaptabilních sídelních struktur. V jednotlivých př́ípadech sídel je zjištováno, zda lze vysledovat různorodost funkcí a vazeb - multimodalitu - a hierarchické uspořádání. Je sledováno, jak se struktura vyvíjela - vlastní sebeorganizací, nebo řízeným plánováním shora. Výzkum není dosud uzavřen.

Ne všechny sledované vlastnosti lze určit jednoznačně a je pravděpodobné, že škála hodnoticích kritérií bude muset být upravena tak, aby bylo možné některé vlastnosti sledovat.

Výsledky výzkumu dle očekávání naznačují, že větší sídla poskytují bohatší škálu zajištovaných funkcí a více vazeb, vícenásobně strukturovaných (mají např. rozvinutější dopravní infrastrukturu), současně jsou flexibilnější a adaptabilnější.

Předpokladem je, že výsledky budou směřovat ke zjištění, že dlouhodobě a postupným vývojem formované struktury jsou trvanlivější a adaptabilnější (typicky jádrová území). Další výzkum by se měl zaměřit na vysledování dalších charakteristik elastické struktury tak, aby bylo možné popsat její znaky. Ty by mohly být dále sledovány v procesu územního plánování tak, aby elasticita sídelní struktury byla chápána jako hodnota pro utváření kvalitního prostředí sídel.

\section{Prameny}

ALFASI, Nurit a Juval PORTUGALI, 2004. Planning Just-in-Time versus planning Just-in-Case. Cities,. Great Britain: Elsevier Ltd., 21(1), 29-39. DOI: 10.1016/j.cities.2003.10.007.

BETTENCOURT, Luís M. A., José LOBO, Dirk HELBING, Christian KÜHNERT a Geoffrey B. WEST, 2007. Growth, innovation, scaling, and the pace of life in cities. PNAS. 104(17), 6. DOI: doi.org/10.1073/pnas.0610172104.

LÖW, Jiří a Igor MÍCHAL, 2003. Krajinný ráz. 1. vyd. Kostelec nad Černými lesy: Lesnická práce. ISBN 80-863-8627-9.

MEHAFFY, Michael W., 2015. Design for a living planet. Portland, Oregon: Sustasis Press. ISBN 978-0-9893469-5-5.

PORTUGALLI, Juval, 2000. Self-Organization and the City. 1. Berlin, Heidelberg: Springer Berlin Heidelberg. ISBN 978-366-2040-997.

POTOČNIK, Tina, 2013. Razvoj in preobrazba primestnih naselij s primerom naselja Mengeš. (Development and transformation of suburban settlements with the case study of Mengeš.). Ljubljana. Finished PhD research. Univerza v Ljubljani, Fakulteta za arhitekturo. Vedoucí práce Prof.dr. Peter Fister, doc. Natasa Koselj. 